\title{
Abbe Guinot: Teaching Logic during the 18th Century to Increase Scientific Abilities
}

\begin{abstract}
Olivier Perru
Université Lyon 1

In 1778, Abbe Guinot, a priest native of Lorraine and professor in the seminary of Toul, published in Nancy the two volumes of his philosophical lectures, whose subtitle is "On Logic.” This concerns a general philosophy of knowledge and a critic of philosophical systems. Guinot is interested in science and natural discoveries. He describes the organization of institutional science and appreciates the progress of sciences but he makes a distinction between scientific progress and philosophers' sophisms that he criticizes. In order to favor science and avoid philosophical errors, logic is essential in students' training. According to Guinot, logic allows us to extend our intellectual abilities, uplift our ideas, help our thought processes, and mature our reflection. However, this logic refers to the great book of nature written in mathematical language. Guinot thinks that scientific experiment is of the highest importance for accuracy of mind. This logic lecture is inspired by Aristotle but above all by Port-Royal Logic. It gives a place to Locke empiricism and it favors development of sciences. Abbe Guinot was a chaplain in the cathedral of Nancy; he emigrated in 1791. He came back in France during the Consulate and he died a few time later.
\end{abstract}

Keywords: logic, 18th century, education, Port-Royal Logic

\section{Introduction}

In 1778, Abbe Guinot, a priest native of Lorraine and professor in the seminary of Toul, published in Nancy the two volumes of his philosophical lectures, whose subtitle is "On Logic" (Guinot 1778). Abbe Guinot tries to lean on Locke and Condillac (the two authors the most quoted in Guinot's works). Sylvain Auroux explains that professional logicians do not exist during the 18th century (Auroux 1995). Logical works are linked to metaphysics and philosophy of knowledge. Logic field is extended as far as the reign of reason. Logic exists in order "to develop the mind" (Bertrand 1764), "to contribute to clearness and extension of knowledge" (Crousaz 1712); it contains "the germ of all knowledge" (Guinot 1778). Logic guides "the intellectual strength" (Wolff 1763); it proposes “an art of judging” (Boisgelin de Cucé, 1789) or "a way of well-thinking” (Bouhours 1687) (Auroux 1995, 133). All these viewpoints are present in the book written by Guinot.

In a book entitled The Lazarites in the Diocese of Toul before the Revolution (1635-1791), we can read:

Abbe Guinot, from Neufchateau, was blamed for having been one of the first authors of the disturbances in the seminary of Toul, during the last times of bishop Drouas, of which the result was the eviction of some seminarists, accused of deism and materialism. Senator François de Neufchateau has been suspected of having been their leader. He justified himself in a

Olivier Perru, professor in History and Philosophy of Sciences; Sciences, Société, Historicité, Education, Pratiques, E.A. 4148 S2HEP, Université Lyon 1 and ENS-Lyon, France; main research field: History and Philosophy of Biology, Philosophy of the Living, Science and Religion. Email: olivier.perru@univ-lyon1.fr. 
memoir against Guinot. Guinot was a chaplain in the cathedral of Nancy; he emigrated during the Revolution and he died as he came back to France. (Felix Contassot 1970, 71)

This is an interesting remark taking into account the introduction of some ideologies in the seminaries, about the year 1770. As the seminary of Toul was closed in 1778, Guinot became a chaplain and a member of the chapter of the cathedral of Nancy up to 1790.

\section{Philosophy, Science, and Logic in "Philosophical Lessons" of Abbé Guinot"}

From the Opening Address, Guinot focuses on the progresses in scientific knowledge during the 18th century. "We have seen some observers as enlightened as tireless who follow the most hidden processes of Nature. They grabbed her secret to Nature about individual development, propagation of species, and linking between kingdoms. Some new Plines have classified about more than 25,000 plant species...” (Guinot 1778, I; VI). The viewpoint of Guinot on naturalist discovered during the 18th century is positive. Guinot notices the organization in institutional science, the multiplication of scientific societies but he distinguishes this progress in sciences from the "sophisms" of philosophers. It is the classical theme of the refutation of the sophists, who are the French philosophers of the 18th century. One century later, this theme will become the war against the "wrong science."

Abbe Guinot writes: "Beside these great men, whose the strengths obviously aim to illustrate (to honor) their time and who tend to discover the truth, how many authors are as ingenious as them but may be more appealing? They take advantage of their superiority in order to substitute sophism to truth. So, they throw the seeds of the discord in the middle of the peaceful society" (Guinot 1778, I; VI). ${ }^{2}$ According to Guinot, we may think that logic will be essential in education in order to know the sophisms and fashionable mistakes and avoid or reproduce them. It is an essential theme during the 18th century but still today.

Moreover, education is an essential axis in the intellectual labor of religious people during the 18th century. They work and write more to educate and train the young minds as in a research skill.

If a young man is early educated by strong principles of the right philosophy, if he can see the torch of reason in front of him, or if he is informed of the salutary precepts of virtue, he bears a fecundity in his soul... Great maxims will have nourished his soul. They will give inerasable impressions to him; these impressions will remind him the useful truths. And probity will soon transform him in a good citizen, in a friend of humanity, a model of the right man, deeply rooted in virtue. (Guinot 1778, I; XIII)

We are in the year 1778. In Guinot's book, the reader is amazed by the absence of religious references (Guinot is a priest!): the torch of reason, the precepts of virtue, the maxims nourishing our soul, and the friendship of humanity. These themes precede the French Revolution; for instance, the same themes are found in Mirabeau's works. In the years 1780, an educational challenge in the Church is to carry on with the Christian educational work with an enlightened philosophy, paradoxically supposed fighting against the Enlightenment.

According to Abbe Guinot, teaching philosophy is the true problem in education. Scholastic has been criticized and abandoned, but how to make easier an introduction to philosophy? Teaching philosophy with syllogisms is difficult; however, reflections on knowledge and logic are necessary. In fact, Guinot substitutes logic and philosophy of knowledge for scholastic. But he falls in the same mistakes. He does not consider human experience in philosophy, but the basis of his educational thought is logic and critical reasoning (even if critical reasoning is more philosophical than theological in Guinot's book). Logical reasoning is made more human with style and with a flexibility of reflection. Against the Enlightenment, some philosophies of the 18th 
century are invited. "The works of Pascal, Arnauld, and above all Fenelon and Malebranche, showed it was possible to put together the attractiveness of style, the strength of reasoning, and the linking of proofs" (Guinot 1778, I; XXIII). Finally, Guinot wants to maintain the advantages of logic (with the syllogisms). However, he wishes an opening on a philosophical thought.

I have considered philosophy as the sum of the acquired knowledge by human reasoning and Logic as a key of philosophy, or rather as the first introduction to this knowledge; but where is this knowledge in order to catch its principles and notions? In our soul, doubtless, because our mind generates, enlarges and perfects them. Studying our faculties, we can discover nature and progress that constitute the true philosophy. (Guinot 1778, I; 7)

Logic would be "an art to lead our mind to search for the truth" (Guinot 1778, I; 7-8). It is clear that the author is in a philosophy of ideas. Searching for the truth would be less a discovery of the reality than an efficient reasoning, logic, leading the mind to the truth.

Logic avoids wrong reasoning and such difficulties, but to use logic as the main way for the research of truth is necessary to build a new scholastic with concepts and claims, without references to human experiences. Guinot considered logic as a tool to extend our intellectual abilities; he was searching for a method in order to make human mind as efficient as possible. "Logic has principally to deal with enlarging ideas and giving a dynamics to imagination, giving help to reasoning and combinations, maturing reflections," and so on (Guinot 1778, I; 8). However, Guinot takes care to remind that concepts and judgment precede reasoning; logic reasoning is a tool in searching for the truth. But such logic is also a tool in science.

\section{Aristotle's or Occam's Logic? The Role of the Port-Royal Logic}

According to Abbe Guinot, definition is the first step to build logic. Neither Aristotle nor the Scholasticism set definition as a foundation of logic. During the 17th century, the Port-Royal Logic gives an importance to definition. A definition expresses the more appropriate difference within a kind. The Port-Royal Logic insists on the correspondence between name and definition from a kind and a specific difference. But the Port-Royal Logic takes the risk of absorbing a sum of properties in the specific difference. According to Guinot, the definition includes the properties or characters of an object; it is "an explanation of the principal qualities of the object” (Guinot 1778, I; 15). Definition must be clear, short, and exact. This is very important for the development of descriptive sciences during the 18th century. Sylvain Auroux explains that, in many books of the 18th century, "Port-Royal gives possible ways and an underlying system” (Auroux 1993, 89).

The "kind" is insufficient to establish a classification. In fact, it was a logical problem at the end of the 17th century (before the Linnaean classification). Abbe Guinot works on the nature of definition, with "kind" and "specific" difference, insisting on clarity and simplicity. After definition, Guinot tackles description. In fact, he uses logic in order to take on the scientific questions of the 18th century. Collecting the characters of an object in order to combine a kind to a species is a classical problem in natural history. "To describe" is a scientific question at the order of the day; the survey of the living world implies classification and description. Because defining anything is uneasy or impossible, we need description. "We can define all the diverse properties of the things," writes Guinot (Guinot 1778, I; 32).

This importance given to the definition is characteristic of a terminist logic, this is not new during the 18th century. But Guinot insists on the univocity of language too; this univocity was essential to the development of the sciences at this time. The author wants to avoid the arguments around the diversity of meaning of the words. He mentions that the plurality of meanings of certain words is an origin of some sophisms. Finally, words are 
signs as mathematical signs and these signs refer directly to signified things. This point of view is very important in scientific education: Are words some translations of our concepts in a language or are they signs (as in mathematics) directly referring to things and systems? According to Guinot, the judgment refers to the analysis of a complex idea. The author has taken back what seemed to be a useful knowledge in Aristotle's Logic. The analysis of combined propositions implies Stoicism's Logic.

As for Descartes, logic is useful in scientific education of young people, especially in order to reveal the sophisms. A usefulness of logic is to avoid the handling of the minds of young people by the philosophers' wrong reasoning. "Sophism consists in the matter or in the form of reasoning. It consists in the matter of reasoning if the judgment itself is wrong... it consists in the form of reasoning... if the relationship between the principles and their later consequences is only apparent” (Guinot 1778, I; 108-9).

\section{Conclusion}

Philosophical lectures of Guinot are in fact lessons in critic of knowledge. Firstly, Guinot refutes Descartes, and then he refutes Malebranche to adopt rather Locke’s philosophical system. Experiment is the used criterion. In education too?

At the end of the 18th century, the thought of Malebranche has not carried its promises out; this philosophy gave neither a satisfactory philosophy to the Church, nor a thought on sciences. So Guinot is interested in Locke's philosophy. From the first lesson, Guinot insists on experience as a starting point of philosophy and on experiment as a starting point of science. He celebrates experience (experiment) as a source of renewal and progresses in sciences. "Apparently, there is an only way to lead us to demonstration; this way is experience (experiment)...” (Guinot 1778, I; 125).

Celebrating experience concerns logic too. Abbe Guinot is always in this perspective of renewal of logic. "If it is possible to gather a big enough number of phenomena together concerning the mind operations and if their repetition would be constantly uniform, this science will clearly take part to the same prerogatives than the others and likewise will get the most infallible certainty” (Guinot 1778, I; 125-6). So, logic is very important in teaching.

So, according to Guinot, the idea is to do an experimental study of some mind operations, and by an inductive approach, to establish the logic laws for reasoning and mind. Guinot is searching for establishing the laws of mind, as scientists discover physical laws at the same time.

\section{Notes}

1. About Guinot and his “Philosophical Lessons,” see Perru, 2012.

2. I give my translation of the texts written by Guinot.

\section{Works Cited}

Auroux, Sylvain. The Logic of Ideas. Paris: Vrin, 1993.

---. “Argumentation et anti-rhétorique, la mathématisation de la Logique classique.” Hermès 15 (1995): 129-43.

Boisgelin, de Cuce, Jean de Dien, Raymond (de). The Art of Judgment by the Analysis of Ideas. Paris: Moutard, 1789.

Bouhours, Dominique. A Way of Good Thinking in the Works of Mind, Dialogues. Paris: Mabre-Cramoisy, 1687. 
Contassot, Felix. The Lazarites in the Diocese of Toul before the Revolution (1635-1791). Monographs Houses: Toul Seminaire. De Paul University, 1970.

Crouzas, Jean-Pierre (de). New Essay in Logic. Amsterdam: F. Honore (2 vol.), 1712.

Guinot, Abbe. Philosophical Lessons, On Logic, I. Nancy: Mathieu, 1778.

Perru, Olivier. Clergymen and Science during the 18th Century: Towards a Harmony between Reason, Nature and Creation. Paris: Vrin, 2012. (Book in French. French title: Hommes d'Eglise et Science au XVIIIe siècle: Vers une harmonie entre Raison, Nature et Création).

Wolff, Christian. Logic or Rational Thoughts on the Powers of the Human Understanding: With Their Use and Application in the Knowledge and Search of Truth. Berlin: Haude, 1736. 